\title{
EGYPTIAN SCHOOL OF STEM AND THE NEEDS' FOR THE LABOUR MARKET OF TEACHER OF EXCELLENCE THROUGH HIGHER EDUCATION
}

This study aims to generate a conceptual framework for Egyptian School of STEM and the Needs' for the Labor Market of Teacher of Excellence through Higher Education, specialized Science, and Technology, Engineering, and Mathematics (STEM) schools. There are 14 schools of STEM as examples of STEM-oriented programs and state initiatives. The schools exist and demonstrate what is possible for the national STEM agenda. Each program, no matter its place on the continuum of approaches to STEM, needs an explicitly stated goal and specific strategies for achieving that goal as the Needs' for the Labor Market of Teacher of Excellence through Higher Education. The current perception for these schools can be described as unique environments including advanced curriculum, expert teachers, and opportunities for internships and immersion. Researchers have categorized these schools with three types (selective, inclusive, and focused career and technical education). Messaging and marketing campaign that changes school culture and raises the prominence of STEM must be in place. Parents and community members should see that science, technology, engineering, and mathematics matter for the students, and adjust curricular expectations accordingly. Science and technology can no longer be perceived as mere enrichment, second in value to language arts and mathematics. Many schools have already learned the hard lesson that encompasses more than developing reading and scientific writing skills, and engaging in literary analysis. Content reading and writing skills, as well as evaluating evidence from non-fiction texts, now appear in the Common Core State Standards for English Language Arts. STEM education gives students access to disciplinary skills that are essential to a productive life in Egyptian School of STEM. By synthesizing the literature, we created a conceptual framework of effective learning environments for STEM schools included students, teachers, community leaders, and role models, as well as contextual factors.

Keywords: egyptian school, STEM, labor market, teacher of excellence, higher education.

ЕЛСАСД А. ЕЛЬНАШАР, ЗЕЙНАБ Е. ЕЛЬНАШАР

Кафр-ель-шейх університет, Єгипет

\section{ЄГИПЕТСЬКА ШКОЛА SТЕМ ТА ПОТРЕБИ У ВИКЛАДАЧАХ ВИЩОЇ КАТЕГОРІЇ НА РИНКУ ПРАЦІ}

Дане дослідження спрямоване на створення концептуальної основи для єгипетської школи STЕМ, до якої відносять вищі навчальні заклади, що викладають спеціалізовані науки та технології, техніку та математику (STEM). 14 STEM-шкіл, як прикладів STEM-орієнтованих програм та державних ініціатив, існують і демонструють те, що можливо для національної програми STEM. Кожна програма потребує чітко визначеної мети та конкретних стратегій для досягнення цієї мети. Ці школи можна описати як унікальні середовища, що включають передові навчальні плани, вчителів-фахівців та можливості для стажування. Дослідники поділили иі школи на три типи (вибіркове, всеохоплююче, цілеспрямоване професійне та технічне навчання). Автори відмітили необхідність створення програми обміну повідомленнями та маркетингової кампанї̈, яка змінює шкільну культуру та підвищує популярність STЕМ. Батьки та члени спільноти повинні бачити, що наука, технологія, інженерія та математика важливі для студентів, і відповідним чином адаптувати навчальні плани. STЕМ освіта дає студентам доступ до дисциплінарних навичок, які є важливими для продуктивного життя в єгипетській школі STЕМ. Таким чином, в результаті синтезу даних літературних джерел, створено концептуальну основу ефективних навчальних середовищ для шкіл STЕМ, включаючи їх учасників (студентів, вчителів, лідерів громад) та контекстуальних факторів.

Ключові слова: єзипетська школа, STEM, ринок праці, викладач досконалості, вища освіта.

\section{Introduction}

Education strategy of the Egyptian university education, its mission and its basic values, is determined by the vision of supporting educational institutions and schools. STEM is an academic educational institution that promotes educational knowledge and skills and its applications to serve the community and the world and form the world of teaching and learning.

Therefore, it works to develop education at all levels, both in pre-university education and higher education, in order to achieve comprehensive and sustainable human development for the Egyptian and Arab society. Moreover, it works in communication with the Arab and foreign world [1], the Ministry of Education, public and private schools, and other ministries concerned with education such as culture, information, youth and sports, among others. The main message of this mission is the direct role of a teacher in the formation of a continuous teacher. Besides that, the message is preparation of a distinguished teacher as well as promotion of educational and action research. It helps to produce educational knowledge and pre-service development as well as to develop policies and programs, which serve the society and its development, professionally [9, 14].

Egyptian school of STEM and the needs' for the labor market of teacher of excellence through the higher education was originally called Science, Mathematics, Engineering and Technology (SMET) [5, 15]. It was an initiative created by the National Science Foundation (NSF). This educational initiative was to provide all students with critical thinking skills that would make them solvers of creative problems and ultimately more marketable in the workforce. It is perceived that any student, who participates in STEM Education, particularly in the K-12 (secondary school) setting would have an advantage if they chose not to pursue a post-secondary education or would have an even greater advantage if they did attend college, particularly in a STEM field $[2,3,5]$. 
The increased emphasis on STEM as a component of economic development and competitiveness has mandated increased attention toward STEM in schools [4, 11, 14]. There have been movements in response to the mandate that were designed to address the need for increased attention toward STEM education and shift how we teach STEM to K-12 (secondary school). The resulting STEM education initiatives include the Common Core State Standards-Mathematics (CCSS-Math) and the Next Generations Science Standards (NGSS) [12, 13, 14]. The anticipated outcome of these STEM education standards is an application or practice-based approach to K-12 (secondary school) STEM teaching and learning. An expected outcome is an increase in the number of students well prepared for postsecondary education and workforce entry. There is also the anticipated outcome of increasing the number of students interested in pursuing STEM careers, particularly in high need areas such as engineering [5, 14].

Although the use of STEM concepts (historically) were being implemented in many aspects of the business world; i.e., the Industrial Revolution, Thomas Edison and other inventors, it was not being utilized in traditional educational settings. The Egyptian School of STEM and the Needs' for the Labor Market of Teacher of Excellence Through Higher Education and the use of STEM was primarily used in engineering firms to produce revolutionary technologies such as the light bulb, automobiles, tools and machines, etc. Many of the people responsible for these innovations were only slightly educated and/or were in some type of apprenticeship. For example, Thomas Edison did not attend college [1], nor did Henry Ford; although Ford did work for Thomas Edison for a number of years. These "giants" of innovation used STEM principles to produce some of the most prolific technologies in history. However, STEM in education was virtually non-existent $[2,5,14]$.

\section{Program Description of Egypt STEM Schools [16]}

The Egypt STEM Schools Project provided a springboard for the country's youth to succeed through innovative science, technology, engineering, and math (STEM) education. World Learning, in partnership with the Franklin Institute, the $21^{\text {st }}$ Century Partnership for STEM Education, the Teaching Institute for Excellence in STEM, and the Egyptian Ministry of Education (MoE), developed a network of eleven STEM high schools that embody trans-disciplinary collaboration, real world applications, and critical thinking. This initiative directly supports a new vision of Egypt as a country equipped with both the human capital and institutional resources to compete and excel in the international marketplace. Program Goals are as follows [16]:

- increase student interest, participation, and achievement in science and mathematics;

- $\quad$ strengthen the STEM school initiative by developing an effective model for specialized high schools;

- build the capacity of a highly qualified cadre of STEM professionals and provide opportunities for training and sustained, intellectually rigorous professional learning;

- $\quad$ strengthen MoE capacity at the systems and policy level to sustain and replicate these model schools;

- $\quad$ support the MoE in upgrading science and mathematics curriculum standards, student assessments, and teacher preparation for mainstream schools.

\section{Definition about the "T and E" of STEM Education}

Science: the systematic study of the nature and behaviour of the material and physical universe, based on observation, experiment, and measurement, and the formulation of laws to describe these facts in general terms (Science).

Technology: the branch of knowledge that deals with the creation and use of technical means and their interrelation with life, society, and the environment, drawing upon such subjects as industrial arts, engineering, applied science, and pure science (Technology) [9].

Engineering: the art or science of making practical application of the knowledge of pure sciences, as physics or chemistry, as in the construction of engines, bridges, buildings, mines, ships, and chemical plants (Engineering).

Mathematics: a group of related sciences, including algebra, geometry, and calculus, concerned with the study of number, quantity, shape, and space and their interrelationships by using a specialized notation (Mathematics).

The Definition "T and E" of STEM Education appears to be a stumbling block to producing a meaningful STEM experience to K-12(secondary school) education students. There are several possible reasons for this and they are as follows [5]:

1) as it was mentioned before Science and Mathematics are the most recognizable fields in STEM Education and most educators in these areas feel comfortable teaching them;

2) many educators, which are not in the fields of Engineering and/or Technology, are intimidated with processes that are associated with them;

3) although Engineering is a recognizable word, which most educators can somewhat relate, many who are not in the fields are not sure what engineers actually do in terms of education;

4) many consider Technology as just a computer related field;

5) many educators are comfortable in their fields and create "educational silos".

\section{Definition Technology Education}

Definition Technology Education has a long and rich history not only nationally, but globally as well. As society evolved from the Agrarian Age, to the Industrial Revolution and now the Information Age, through several paradigm shifts, Definition Technology Education has grown and expanded and is now in the midst of yet another paradigm shift [1]. The current shift is aligning science, engineering and mathematics with Technology Education in what is called the integrative STEM initiative [2]. An extra emphasis on engineering specifically is also being called 
for by many technology educators. Furthermore, the trend indicates that several institutions of higher learning are changing the names of their programs to Engineering and Technology Education [5, 9, 10].

In most dictionaries, technology is defined as "applications of tools and methods" or something similar. To the general public, and especially in education, the term technology is spelled "c-o-m-p-u-t-e-r-s," equating "technology" to one technological tool. A computer is a tool, but provides a very narrow view of the scope of technology as a whole. Computers are definitely one form or type of technology, but technology is much, much more than computers alone. Technology encompasses several different constructs that have been categorized by several state and national programs, organizations and standards. They include: Bio and Medical Technologies, Construction, Engineering and Manufacturing Technologies, Electronics, Energy and Power, Information Technologies and Transportation. Within these constructs are a plethora of sub-technologies. For example, Energy and Power technologies can include sub-technologies from automobile engines to green energy sources such as solar and wind energy [5].

\section{Definition Technology and Engineering Education}

Definition the study of technology and engineering, defines technology as "how humans modify the world around them to meet their needs and wants or to solve practical problems." Thus, Technology and Engineering Education is problem-based learning by students utilizing math, science, engineering and technology principles. These studies involve [5]:

- designing, developing, and utilizing technological systems [10];

- open-ended, problem-based design activities;

- cognitive, manipulative, and effective learning strategies;

- applying technological knowledge and processes to real world experiences using up-to-date resources;

- working individually as well as in a team to solve problems.

Definition Educational Technology and Technology Education

Technology Education is a problem-based learning by students utilizing math, science, engineering, and technology principles. Educational Technology (also referred to as Instructional Technology) is the use of technology to educate students.

Instructional Technology is the theory and practice of design, development, utilization, management and evaluation of processes and resources for learning. Thus, Educational Technology uses technology (mainly computer-based) in pedagogical methods of instruction and assessment [17]. This can include the use of PowerPoint, Blackboard, digital assessment programs, Web searches, DVDs and videos in addition other instructional multimedia [5]. Technology Education teachers may use educational technology to deliver lessons and for assessment. However, the confusion between the two disciplines is clearly a problem for most educators. The leaders in Technology and Engineering Education recently made a name change from "Technology Education" to "Technology and Engineering Education" in an attempt to alleviate the confusion and have a solid identity within the educational community $[5,17]$.

\section{Theoretical Framework of Labor Market Mobilization}

Complementary Planet Knowledge (CPK), analysis detailed examination of the elements of the cooperation in STEM invention, and it symbolizes direction shift towards systemic, open and user is main point of interest. Innovation policy. A covenant of development, more extensive of production and linear services led by experts allows for different forms and levels of co-production with consumers, customers and citizens. As defy to public organization authorities and the production of public services, the debate on knowledge about the planet is directly related to the Vision 2030 Vision for Smart STEM and Sustainable and Inclusive Growth, and thus shifts to better stakeholder communication and smarter use of resources advocated by many Egyptian states [6].

\section{Research questions}

What are the roles of Egyptian School of STEM and the Needs' for the Labor Market of Teacher of Excellence education in fostering labor market mobilization?

Does the Egyptian Faculties of Education adopt innovative practices?

What are the challenges to labor market mobilization of Egyptian School of STEM and the Needs' for the Labor Market of Teacher of Excellence education in Egypt?

How Egyptian School of STEM and the Needs' for the Labor Market of Teacher of Excellence education can improve their innovative capacity?

\section{Research Objectives:}

- to explore the roles of Egyptian School of STEM and the Needs' for the Labor Market of Teacher of Excellence through Higher Education in fostering Labor market mobilization;

- to analyze the activities of Egyptian School of STEM and the Needs' for the Labor Market of Teacher of Excellence through Higher Education and the similar authority in other countries that have distinct experiences in promoting innovation;

- to examine the challenges to Labor market mobilization of Egyptian School of STEM and the Needs' for the Labor Market of Teacher of Excellence through Higher Education;

- preparation and sustainable development of professional teachers of Egyptian School of STEM and the Needs' for the Labor Market of Teacher of Excellence through Higher Education in order to improve Egyptian faculties of textiles education.

\section{Experimental Work and Methodology}




\section{Methodology}

In order to achieve the main objective of the current study it is necessary to perform the following activities

types:

- $\quad$ active participation of scientific papers from some schools to analyse the current situation;

- comparative scientific studies in the development of teacher preparation systems, and global trends;

- two workshops attended by more than 25 experts and of Egyptian School of STEM;

- $\quad$ approve proposals for Egyptian School of STEM development policies;

- $\quad$ expert meetings to present procedural proposals and prepare the pilot model;

- discussion of the proposed model at the meeting of Egyptian School of STEM.

Quality education is a research method that results in words instead of statistics. Its research is based on a person's behavioural life in the organization of STEM education, interaction between nations and the cultural phenomenon. The study of qualitative research focuses on personal experience in STEM institution. It is based on description and detailed examination of the elements rather than use of numbers. It is also flexible to verify responses from participants because the information contained in this paper can be a source through a relative educational approach to the STEM.

The reasons for choosing the method are that they are related to the nature of the Egyptian School of STEM research problem. They are suitable for investigations such as organizations, people's lives, thereafter in addition related to finding the nature or meaning of human experience. Besides, they have enough complex information in trajectory with the suggestions of authors of $[8,7]$.

\section{Data Collection}

Research of Egyptian School of STEM and data collection on the latest Egyptian School of STEM programs were conducted in seven countries across five of the most successful international experiences to benefit from. The data of the previous experiments were analyzed and the results presented to a group of workshops.

\section{Workshops}

The first workshop attended was entitled "Towards Instructional model for the development of Egyptian School of STEM". Places of the workshop locations are as follows: Sector Committee, Giza and Holiday Inn-Maadi, Cairo, Egypt. The issues discussed are as follows: specifications of the graduate; the component of public culture in teacher preparation program; sustainable professional development, and Egyptian School of STEM.

\section{Results and Discussions}

Personal and societal decisions in the $21^{\text {st }}$ century increasingly require scientific and technological understanding. Whether about health, the environment, or technology, a certain level of scientific knowledge is vital to informed decision making. Thus, another goal of STEM education is to prepare citizens to face the challenges of a science- and technology-driven society.

Egyptian societies and school-level achievement test data are the most widely available measures and the measures used for accountability purposes. Therefore, they are the measures most commonly used to gauge success, regardless of the goals of a particular school or program. Although it is difficult to measure interest and motivation ("joy at the prospect of discovery"), creativity ("a culture of innovation"), or commitment to "ethical behavior and the shared interests of humanity," it is essential to do so given the importance of preparing students to be leaders in STEM innovation and not just good test takers.

Successful STEM education also takes place in "regular" comprehensive schools in grades K-12 (secondary school), which educate the vast majority of the nation's students. Egyptian societies includes many talented and aspiring scientists, mathematicians, and engineers who might not have access to selective or inclusive STEM-focused schools. Egyptian societies are generally preparing students for postsecondary success, and emphasizing the development of inquiry and reasoning skills. Effective instruction capitalizes on students' early interest and experiences, identifies and builds on what they know, and provides them with experiences to engage them in the practices of science and sustain their interest. According to the research, effective instruction actively engages students in science, mathematics, and engineering practices throughout their schooling. Students in these schools have opportunities to learn science, mathematics, and engineering by addressing problems that have realworld applications.

However, this type of STEM instruction remains the exception in Egyptian society's schools. Extraordinary teachers who overcome a variety of challenges that stand between vision and reality typically facilitate it. Enterprise to be effective, teachers need content knowledge and expertise in teaching that content, but the research suggests that science and mathematics teachers are particularly underprepared for these demands. Weak initial teacher preparation heightens the importance of continuing professional development, but the available research suggests that professional development in STEM, when available, discipline, and effective professional development should:

- focus on developing teachers' capabilities and knowledge to teach content and subject matter,

- address teachers' classroom work and the problems they encounter in their school settings.

In addition, while provide multiple and sustained opportunities for teacher learning over a substantial time interval the STEM disciplines, districts need to enhance the capacity of K-12 (secondary school) teachers. STEM teachers should have a deep knowledge of their subject matter and "an understanding of how students' learning develops in that field".

1. The number of private schools that adopt STEM education is increasing from 14 to 27 schools. There are 
ministerial decisions to mainstream the STEM philosophy and expand it to include government schools in all stages in all governorates of Egypt.

2. Studies have shown that there is a shortage of teachers to work in these schools locally, regionally and internationally, and this fills the urgent need for the proposed program.

3. There is an urgent need for the proposed diploma in the light of global developments, and the required preparation of chemistry and physics teachers, mathematics, technology and engineering, and English, who are able to bring up a generation of learners able to cope with rapid developments, especially in the areas of science, technology, engineering and mathematics.

4. The need to prepare and qualify teachers through an integrated education perspective that focuses on the development of the skills of innovation, leadership and communication in all these fields through their integration. The following special diploma in education will offer the proposed program - Teaching chemistry, physics, mathematics, technology and engineering, English Language, STEM Education.

5. The need for a teacher capable of addressing the shortcomings of the educational curricula in these areas, and to achieve the quality of education required, in order to provide the labor markets with specialized forces in the field of chemistry and physics, mathematics, technology and engineering, and advanced English.

6. Meeting the requirements of the labor market by preparing specialized forces equipped with the skills required to work in areas related to the past decade has increased the functions related to chemistry, physics, mathematics, technology, engineering, and English, faster than three times.

7. The development of $21^{\text {st }}$ century skills is one of the most important objectives of STEM education. These skills relate to communication skills, complex thinking and communication. This is the focal point of STEM education, which focuses on preparing citizens, who can use their skills and knowledge in finding solutions to problems that will ultimately make people's lives better.

8. The proposed program is expected to meet those needs, with the aim of qualifying teachers specialized in chemistry, physics, mathematics, technology and engineering, and English language, to work in various stages and types of education. It is needed in order to deepen the scientific, educational and applied knowledge of chemistry, physics, mathematics, technology, engineering, and English through the discussion and analysis of theoretical scientific research. Developing concepts, skills and integrated practices in teaching chemistry, physics, mathematics, technology, engineering, and English, in accordance with contemporary global trends in project-based teaching is needed as well.

The graduates of this special diploma in Education - Teaching Chemistry, Physics, Mathematics, Technology, Engineering and English (STEM) will be able to obtain a variety of job opportunities inside and outside the Arab Republic of Egypt.

\section{Feasibility Study of the Proposed Program}

There are special expenses for admission to the proposed program. University will apply to this program all administrative and financial regulations for the credit hours system at the Faculty of Education in respect of registration, tuition, and the general cost of the program.

The faculty members who will be nominated from the Department of Curriculum and Teaching Methods at the Faculty of Education (specialization of curricula and methods of teaching science and mathematics) will participate in teaching in this course. Members of a specialized teaching staff will teach the proposed program. In addition, there are enough faculty members in the department to supervise the practical education program.

The Department of Curriculum and Instruction in the Faculty of Education will supervise the assignment of faculty members to teach related courses in chemistry, physics, mathematics, technology, engineering, English language, among the professors of the Faculty of Engineering and associated colleges.

The Schools of Excellence in Science, Technology, Engineering and Mathematics (STEM) are located in the Arab Republic of Egypt (14 schools, one in the university, which is closed away from the Faculty of Education). Government sources are available to apply the program of practical education in the proposed program. It is worth mentioning that there are many international programs in the Education STEM, including the American model and the various European models, which will be reviewed and used in building the proposed program, but the current program does not follow a specific program. The program was designed and built in accordance with the cultural context of Egypt, satisfying its needs and satisfying its future aspirations in this field and in line with the global trends as well.

\section{Objectives of Diploma}

The diploma aims to qualify teachers who specialize in teaching chemistry, physics, mathematics, technology, engineering, English language to work in different stages and types of education. It aims to deepen the scientific, educational and applied knowledge of chemistry, physics, mathematics, technology, engineering, and English teachers through the discussion and analysis of theoretical scientific research. Therefore, it would be able to develop concepts, skills and integrated practices in chemistry, physics, mathematics, technology, engineering, and English, in accordance with contemporary global trends in project-based teaching. The Diploma aims to produce graduates who are able to work as teachers of chemistry, physics, mathematics, technology, engineering and English language, according to STEM.

The nature of the study and the educational model of the Diploma

The study is based on a Learning Blended learning model that combines distance learning using e-learning technologies (electronic courses, virtual classes, video lectures) and traditional teaching methods to attend university 
headquarters. In all cases, students must attend $75 \%$ in each semester. Each student shall be assigned an academic advisor for follow-up during the selection of courses or preparation of the project.

\section{Evolution of Specialized STEM Schools}

National accreditation in the Egyptian society during the latter half of the $20^{\text {th }}$ century placed more emphasis on education. Concurrently, more SMT schools were created through state wide initiatives. One of the first state initiatives to emerge at this time was a residential summer program for gifted students in Cairo and Giza. In this program, a residential specialized SMT school took the name The Cairo and Giza School of Science and Mathematics.

Over time, each Egyptian governments (14) has made similar progress in founding a residential specialized SMT school for highly capable students and they came together to establish the National Consortium for Specialized Secondary Schools of Mathematics, Science, and Technology. The fourteen founding schools perform the function of a catalyst for advancing STEM education by providing students, teachers, and communities with the means to achieve in a technology driven society. The overall mission of the consortium is to prepare students for success and leadership in STEM, scaffolding communication and collaboration between member schools, transmitting information about current developments in STEM education, and expanding efforts for advanced STEM education. Currently, there are over thousands students and educators in almost 14 institutions. Together, these individuals and institutions work with people in over five additional affiliate collages.

The evolution of STEM education in the last century also included a transition from "manual training schools" to "specialized SMT schools". In the late $20^{\text {th }}$ and early $21^{\text {st }}$ centuries, additional schools took the name "specialized STEM schools." These schools were often created through state and national initiatives designed to address concerns over Egyptian economic competitiveness and the perceived shortage in the STEM workforce. The current perception of most education leaders, policymakers, and researchers for specialized STEM schools can be described as in following sentence. Specialized STEM schools offer a unique and comprehensive environment, which includes an advanced curriculum and opportunities for significant immersion in the work of the field through mentorships, internships, and research apprenticeships that are often beyond what is available in even the best high schools. STEM schools offer a faculty with exceptionally high levels of content area expertise, often consisting of doctorates in content areas; and a select population of students who are homogeneous with respect to ability levels, interests, and aspirations.

\section{Curriculum in STEM Schools}

Results of the study with 14 participating schools indicated that specialized STEM schools were likely to offer research opportunities for students of the schools who conducted research with a faculty member or a mentor. The students continued their research throughout summers with the assistance of a mentor. In addition, students conducted their own research using either a laboratory or off-campus facility. Not surprisingly, students in STEM schools participated in contests to disseminate results of their research. Administrators of six schools indicated that incorporation of STEM is content with the humanities curriculum. While administrators in schools identified a minimum number of mathematics courses for students, only some of schools required a minimum number of science courses.

\section{Conclusion}

In the current study, we focused on specialized STEM schools to answer research questions. These questions were related to the historical background of the learning environments found within these schools as well as the demographic characteristics and college and career readiness of students within the schools. We found these schools are unique and comprehensive environments. In addition, we found critical design components for Establish Diploma for Needs' for the Labor Market of Teacher of Excellence through Higher Education. Moreover, three common models are used to describe Diploma for these schools. Theoretical ideas and empirical findings contributed to this theoretical study. Participatory research on the Diploma provides engagement and negotiation for researchers. We contend the Diploma ecology metaphor can contribute to expanding definitions for the Diploma and understanding of who is involved in learning environments. However, caution must be used when making inferences for specific learning environments from broad generalizations about participants, contextual factors, and actions. Unintended consequences may result without regard for the specific environments.

\section{Acknowledgements}

Thanks and appreciation to Prof. Dr. Hassan Al-Beblawi, Chairman of the Educational Studies Sector Committee at the Supreme Council of Egyptian Universities for his commendation for me to participate and attend the STEM workshops.

Thanks and appreciation to Prof. Dr. Rida Abu Saree, Responsible for the Ministry of Education project for inviting me to attend the workshops.

\section{References}

1. Beals G. Thomas Edison Home Page [Electronic resource] / Gerald Beals. - 2012. - Retrieved from http://www.thomasedison.com/.

2. Will the scientific and technology workforce meet the requirements of the federal government / [W. Butz, T. Kelly, D. Adamson, \& others]. - Pittsburgh: PA: RAND, 2004. 
3. Brody L. Measuring the effectiveness of STEM talent initiatives for middle and high school students. Paper presented at the annual meeting of the National Academies Center for Education / Brody. - Washington: DC, 2006.

4. Carnevale A. P. Science Technology Engineering Mathematics / A. P. Carnevale, N. Smith, M. Melton // STEM. - 2011. Retrieved from http://cew.georgetown.edu/STEM/

5. White D. W. What is STEM education and why is it important? / David White // Florida Association of Tea cher Educators Journal. - 2014. - № 1 (14). - C. 1-8. Retrieved from http://www.fate1.org/journals/2014/white.pdf

6. Elnashar E. A. Faculties of textiles education between challenges and renaissance in the 21 st century for labor market mobilization / E. A. Elnashar // Applied Researches in Technics, Technologies and Education Journal of the Faculty of Technics and Technologies, Trakia University, Bulgaria. - 2018. - P. 108-120. Retrieved from https://sites.google.com/a/trakia-uni.bg/artte/articles/artte-vol-6-no-2

7. Elnashar E. A. Engineering Business Models Of Creative Communities Industrial Of Internationalization Small Firms In Mahalet Marhoum City / E. A. Elnashar, G. Colovic // Tekstilna industrija. - 2016. - № 3.

8. Elnashar E.A. Decision support system for higher education (research examiners \& reviewers) in Egyptian / E.A. Elnashar, A. Heggi // Innovation and Entrepreneurship. - 2017. - № 3. - P. 104-126. Retrieved from http://eprints.ugd.edu.mk/18198/1/Inovaci\%20br\%203.pdf

9. Elnashar E. A. Technology for the renaissance strategy and sustainable development of Egyptian faculties of education / Elsayed Elnashar // Supreme Council of Egyptian Universities, educational studies sector committee (planning committee), project of developing colleges of education, Egypt. - 2017.

10. Elnashar E. A. Education in the professional field "Design" - a comparative analysis of Egyptian and European experience in this study area of higher education" / E. A. Elnashar, Z. Zlatev, P. Boneva // International Journal of Advanced Educational Research. - 2017. - № 2. - P. 5-9.

11. Holdren J. P. Prepare and inspire: K-12 education in science, technology, engineering, and math (STEM) for America's future / J. P. Holdren, E. S. Lander, H. Varmus (Executive Report). Washington, D.C.: President's Council of Advisors on Science and Technology. - 2010.

12. National Governors Association Center for Best Practices, Council of Chief State School Officers. Common core state standards for mathematics. - Washington DC: National Governors Association Center for Best Practices, Council of Chief State School Officers. -2010.

13. A framework for K-12 science education: Practices, crosscutting concepts, and core ideas // National Research Council. Washington, DC: National Academies Press. - 2011.

14. Sanders M. The Technology Teacher / Sanders M. // STEM education. - 2009. - № 68. - P. 20-26.

15. World learning "Egypt-Stem-Schools-Project" [Electronic resource]. - 2018. - Retrieved from https://www.worldlearning.org/program/egypt-stem-schools-project/.

16. Veselina N. Online collaboration for improving the quality of training course for craft tapestry in Egypt / N. Veselina, E. A. ElNashar, Z. Zlatev // ICVL International conference of Virtual Learning - Virtual Reality Models and Methodologies Technologies and Software Solutions, October 28, 2017 at ICVL 2017, Department of Computer Science and Electrical - University of Sibiu, Romania. - 2017. Retrieved from http://www.c3.icvl.eu/2017/accepted-abstract-list.

Рецензія/Peer review : 21.3.2019 p. Н Надрукована/Printed :11.4.2019 p. Стаття рецензована редакційною колегією 